Historic, Archive Document

Do not assume content reflects current scientific knowledge, policies, or practices. 


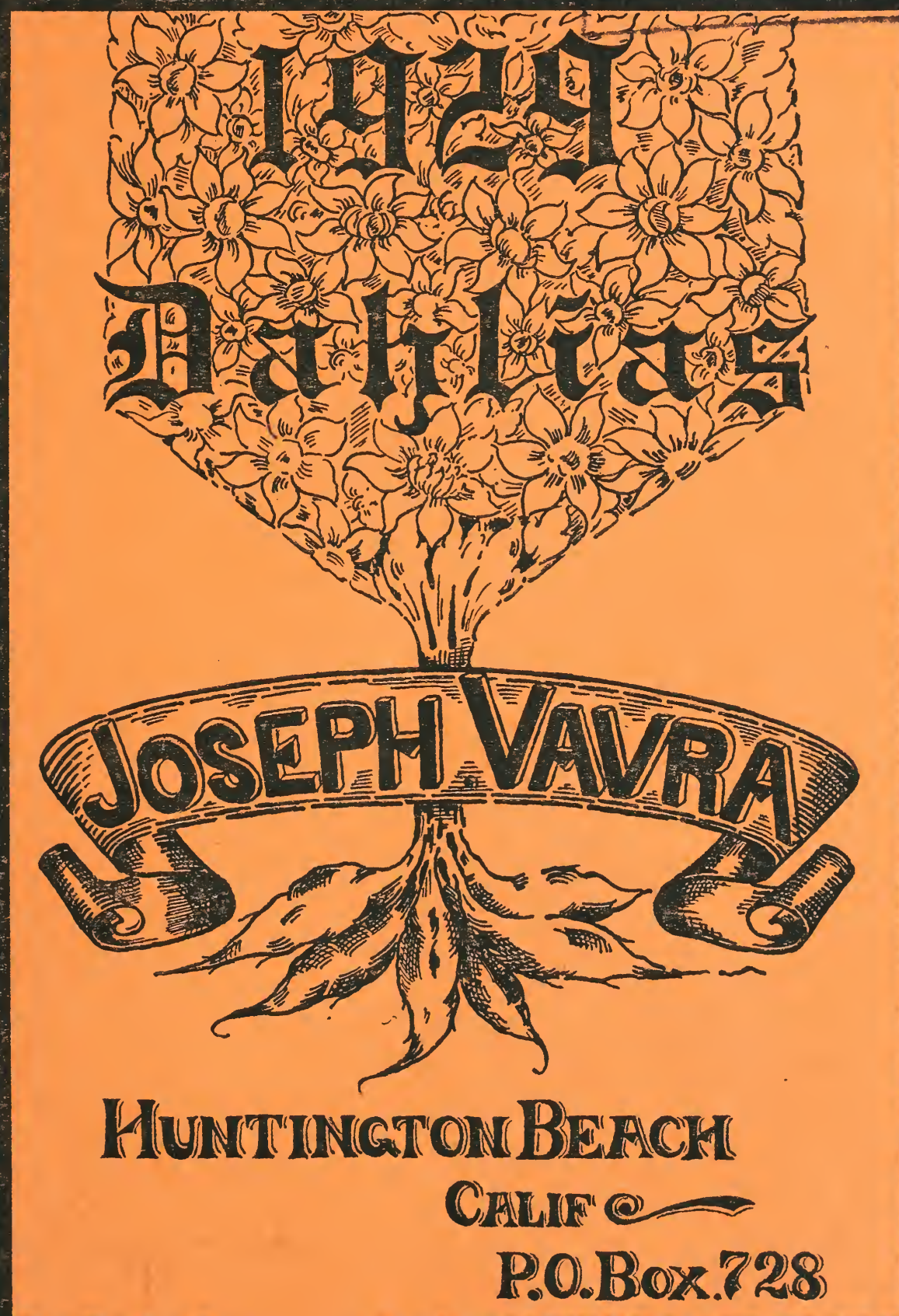





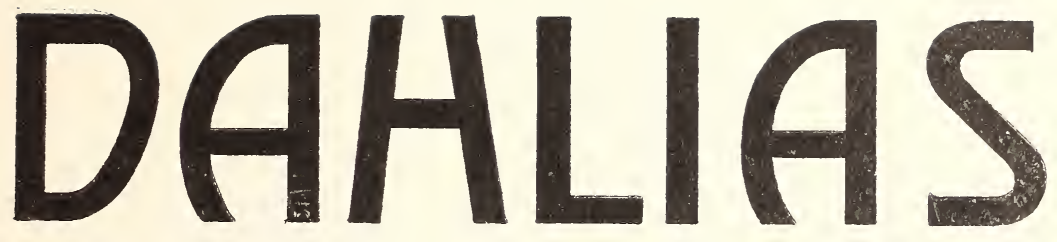

\section{CATALOG AND PRICE LIST}

FOR

1929

\section{SENT FROM \\ CALIFARNIA TA EVERYWHERE}

JOSEPH VAVRA BOX 728

Huntington Beach, California 


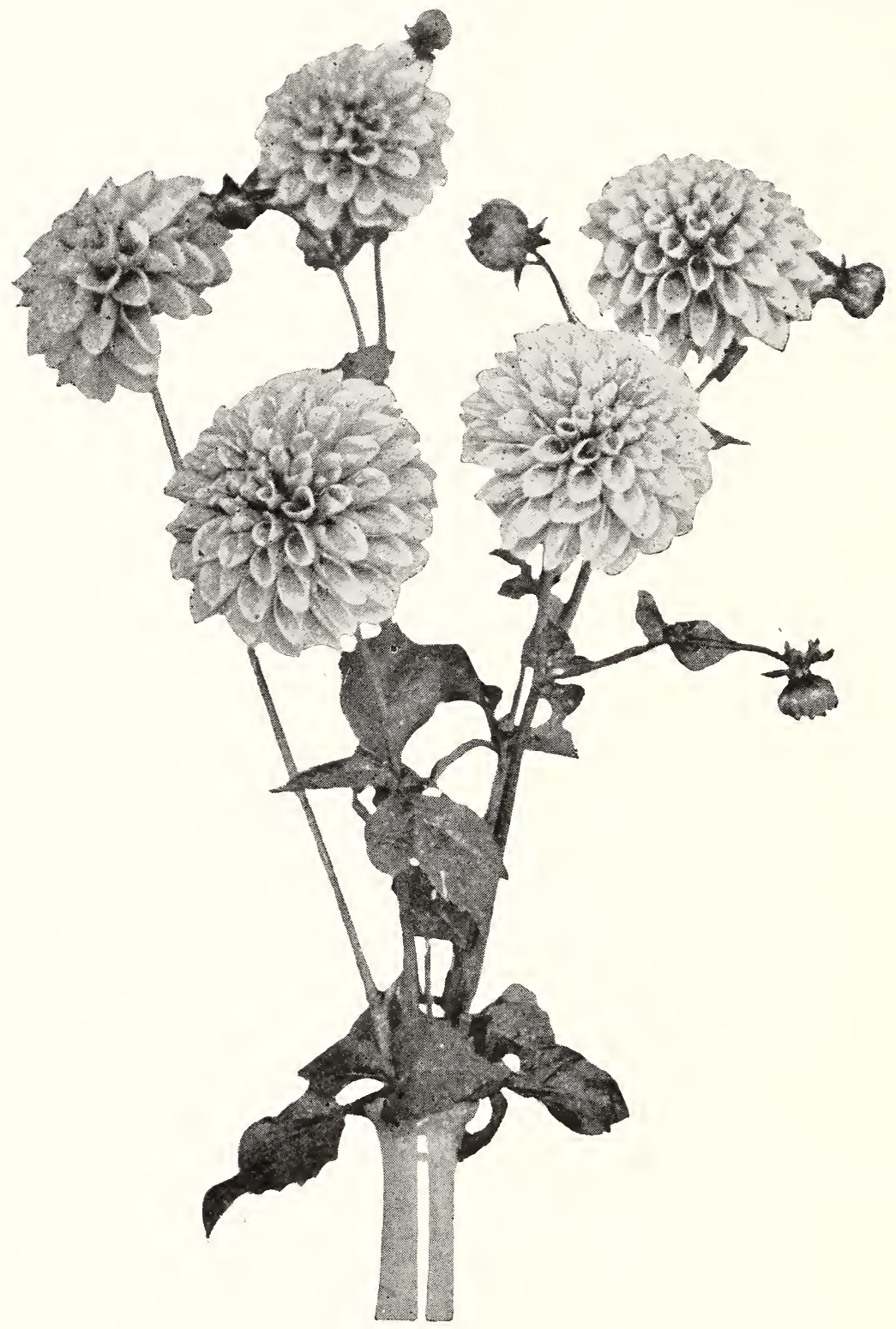

PRINCESS ALINE 


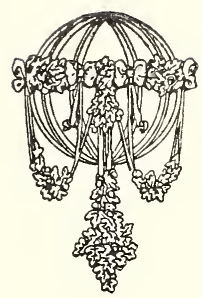

W

take great pleasure in presenting this, the 1929 issue of our dahlia catalog, and take this opportunity to express to our patrons a sincere appreciation of the liberal support that has been accorded us; and also to extend our thanks for the many kind letters we have received, telling us of the successes achieved with our dahlias and dahlia seeds.

The stock we send out is entirely field grown, without the use of any fertilizer whatever, and only the proper amount of water required for a healthy growth is used during irrigation; this can be carefully controlled in Southern California as we have no rainfall whatever during the grow: ing season. So many of the failures in growing dahlias are due to the use of roots from plants which have been heavily fertilized and forced in order to get the maximum quantity of flowers.

Our success in growing dahlias on the large scale that we do depends entirely upon the service and satisfaction we render to our customers, and it is our policy to consider no transaction completed until fully satisfactory results have been achieved with the stock which we send out. Should you, in any way, be disappointed with your flowers, do not hesitate to write us and we will endeavor to assist you in any way we can.

JOSEPH VAVRA.

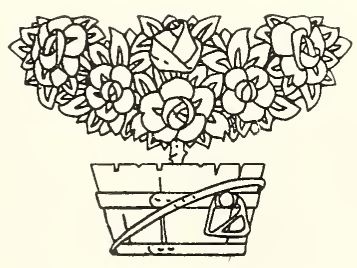




\section{GENERAL INFORMATION}

\section{ORDER EARLY}

By so doing you will be assured of getting all of the dahlias wanted, because every season our stock. of many varieties is booked up even before the shipping season begins. All orders are acknowledged and entered at the time they are received and the roots are reserved, to be sent out when required for planting.

\section{TIME OF SHIPMENT}

This varies for different localities and it will assist $u_{s}$ in filling orders at the proper time if our customers will specify the approximate date they wish to have their roots shipped. We recommend April, May and June as the best months in which to plant, and will use our best judgment as to the me of shipment unless a definite date is specified in the order.

\section{PRICES QUOTED}

Prices quoted are ficr divisions of field grown roots which have not been torced or propagated from, and include the prepayment of postage on all retail orders over $\$ 2.00$. On orders of less amount a charge of fifteen cents is made to cover postage and packing.

\section{SUBSTITUTION}

We do not substitute for any varieties which may be sold out unless expressly permitted to do so, and when placing the order, it is well to make a few extra selections which we may ship in case the supply of some of the stock is exhausted.

\section{OUR GUARANTEE}

All dahlia roots are guaranteed to be true to name as grown by us, and to reach the customers in growing condition; we are ready and willing to replace any that should nove otherwise. However, not having control over the plants after they are set out, it is hardly reasonable to hold us responsible for losses caused y insects, drouth, poor soils, unfavorable locations, or other natural causes. We use the greatest care throughout the growing season to cull out uiseased plants and all that are not true to variety and believe that our stock is as clean as human care can make it.

\section{A FEW POINTS ON GROWING DAHLIAS}

Any soil which will grow good vegetables will grow good dahlias. If too heavy lighten it with barn yard manure, coal ashes or sand. If run down, add fertilizer; barn yurd nianure is best.

Do not plant until after all cianger of frost is over. Place the roots four to six inches deep, laying them down horizontally; do not stand on end.

Vater sparingly during the early stages of growth, but keep the ground well cultivated. Water heavily when the flowers appear, and mulch with any suitable material obtainable.

Do not allow the flowers to die on the bush or go to seed, cut them off in order to have continuous bloom. Cut the flowers with long stems; this will naturally thin out the bush and give you more flowers in the end.

And above all, do not be disappointed or discouraged if you do not grow enormous exhibition flowers on your first attempt. Remember that the mammoth blooms seen at the shows are produced by growers with years of experience.

Complete planting and growing directions are included with each order sent out by us.

\section{FOUR}




\section{NEW INTRODUCTIONS FOR 1929}

We are putting out this season six new dahlias; three of these were developed in our own gardens, two are from Mr. T. D. Hinebauch, of Long Beach, and one from Mr. John Bazant, of Los Angeles. These were all selected according to most rigid standards, and we have given special attention to have them meet all of the requirements new dahlias should have. They are all distinct either in shape or coloring, all are of large size and have the best of stems.

It will be noted that we are not asking an exorbitant price for any of these novelties; this is in line with our policy not to disseminate our new varieties until we have enough stocks of them so that we may price them within the reach of all.

ASPASIA. No. 136. Decorative. A most odd shade of rosolane purple with a golden yellow tinge, the whole having a characteristic smoky appearance; this is a decidedly new color in dahlias and is very pleasing. The flowers are of a regular type, large and abundantly produced on tall bushes. A fine cut flower.

$\$ 1.00$

CORYPHEE. No. 163. Decorative. Scarlet red heavily overlaying a light orange yellow, with the yellow decidedly showing around the edges of the petals. The flowers are of good size in a regular and very double decorative type, and are very freely produced on long and wiry stems; the bushes grow rather tall. A fine cut flower.

$\$ 1.00$

ELEANORA. No. 50. Decorative. Chrome yellow, heavily overlaid with Indian red; the reverse of the petals being veined with mallow purple, while the face appears to be sprinkled with gold dust. The flowers are very large, made up of wavy and twisted petals in a loose formation incllned toward the hybrid cactus type. Stems are exceptionally long and rigid, and the bushes are vigorous and tall growers. A 1925 seedling received from Mr. T. D. Hinebauch, of Long Beach.

$\$ 2.50$

HUNTINGTON BEACH. No. 147. Hybrid Cactus. Orange buff, overlaid with carnelian red and shading off to a bright lemon yellow at the base of the petals; the unopened center shows a heavy carnelian red. This new dahlia came up as a volunteer seedling in our fields about four years ago, and we consider it to be among the best in our collection. It is a husky grower, with heavy leathery foliage on rather tall bushes. The large and deep flowers are made up of broad, twisted and substantial petals, making it an ideal variety for cut flower work, and its keeping qualities are of the best. The stems are long and erect, bringing the flowers well up above the foliage.

$\$ 5.00$

MRS. ANNA SOVAK. No. 293. Hybrid Cactus. Empire yellow, more or less shaded with tawny red, but with a decided layer of the red on the roverse of the petals. This is a seedling from Golden West, raised in 1924 by Mr. John Bazant, of Los Angeles, and is in every way worthy of the parent. The large flowers are beautifully shaped and colored, with ideal stems and keeping qualities, making it a most useful cut flower. $\$ \$ 1.00$

MRS. PRISCILLA HINEBAUCH. No. 32. Decorative. Salmon buff, blending to a coral red center, and a coral red reverse. A magnificent dahlia of a rather loose wavy formation, the inner petals being somewhat fluted. The flowers are very large and very double with full centers and perfect stems, freely produced the whole season on bushes of medium height. One of the best seedlings produced by Mr. T. D. Hinebauch, of Long Bozeh. 


\section{GENERAL COLLECTION}

We are continually trying out new dahlias received from growers of all countries, and discard varieties as soon as they are superceded by something better. Before listing a new variety in this catalog we aim to grow it under our observation for at least two years, or until it is satisfactorily proven to be of superior merit.

The modern dahlia has been brought to such a state of developmenc that a new variety must be nearly perfect as regards stem, color and general habits. Many of the novelties are far from this standard, and, even though introduced at a high price, should really have gone to the trash pile. Experience has shown that the price is no criterion whatever of the value of a dahlia.

The following list contains both old and new dahlias which we can conscientiously recommend to our customers as among the best in the different types and colors.

A. D. LIVONI. No. 236. Show. Clear pink. One of our oldest dahlias and still a great favorite.

35 cents

A.L KORAN. No. 572. Decorative. Clean bright yellow, suffused with amber. The very large flowers are made up of many wavy petals, making a most strikingly beautiful dahlia. The bush makes a vigorous growth and is covered the whole season through with great quantities of the large blooms, held erect on exceptionally long and stiff stems. 50 cents

AMETHYST. No. 846. Decorative. Light violet. A very pretty new dahlia from Holland, which is useful for any purpose. The large dainty colored flowers and long stems make it exceptionally fine for cutting.

50 cents

AMUN RA. No. 333. Decorative. A metallic coloring very hard to describe, appearing to be made up of varying shades of copper and gold, deepening to a full center of deep reddish bronze. The flowers are of the largest size, of a distinct formation, greatly resembling a gigantic water lily and are held up on long, stout stems high above the vigorous growth of the bushes. For cutting purposes they are unsurpassed, lasting for days in water, and the rich metallic coloring blends in with any decorations. This variety has been one of the most popular dahlias ever introduced because of its sterling good qualities. It has one fault, however, and that is the blooms may occasionally come with a hard center; this usually occurs in the early part of the season and the flowers then clear up and come perfect until very late.

$\$ 1.00$

ANDREAS HOFER. No. 187. Hybrid Cactus. Bright pink, shading off to a creamy yellow center. This is a new Holland variety which is exceptionally fine for cut flower use. The medium size, bright and attractive coloring, perfect stems, and keeping qualities will make it an outstanding commercial flower.

$\$ 1.00$

ANNA LANSDOWNE. No. 113. Decorative. White, lightly flushed with lavender pink, giving a general effect of blush pink. The flowers will average six to seven inches across, always a true decorative type and are produced very freely on stiff, wiry stems high above the foliage. The delicate shading and excellent keeping qualities of the flowers make it an ideal variety for cutting purposes.

50 cents 
ARAMIS. No. 155. Decorative. Old gold, heavily tinged with grenadine red; a most desirable commercial variety, in a rich autumn shade. The flowers are of medium size, of a rather loose type with fluted petals and the best of stems which require very little disbudding.

$\$ 1.00$

ARTIS. No. 815. Decorative. Fiery orange scarlet. A new Holland dahlia which is especially suited for commercial use. The flowers are not large but are produced in great quantities on ideal stems. The color is such a rich and brilliant shade that it is suitable for all decorative purposes.

50 cents

ATTILA. No. 100. Decorative. Oxblood red with a rieh velvety, al most black, shading. This is a distinctive novelty in dark dahlias. The flowers are large and deep, perfectly double with full centers; and the petals turn back toward the stem in such a way that the blossoms are almost a ball shape. The stems are long and straight, with bushes of medium height and heavy, dark green foliage.

$\$ 1.00$

AUGUS MEGAR. No. 325. Show. Lavender purple. This is probably the largest and one of the finest dahlias of this type. The plants are sturdy in growth and carry the large, heavy flowers perfectly. 50 cents

BALLET GIRL. No. 101. Cactus. A mixture of white and orange; every bush contains a variety of flowers in different combinations ranging from pure white to pure orange with all the gradations in between, really an entirely new coloring in a flower of this type. The flowers are very large, of the true English cactus type, and while the stems are not perfect by any means, they are much stiffer and stronger than most of the imported varieties. The bushes are of medium height, very free flowering and the flowers stay true to type until late in the season.

50 cents

BERTHA HORNE. No. 21. Hybrid Cactus. Deep orange yellow, tinted with apricot, the latter predominating in many of the flowers. This variety was the first one of our own introductions and has now become one of the standard florists' dahlias the country over. The bush is of rather low growth, the flowers being produced very freely on ideal stems and have the best of keeping qualities. Certificate of Merit A. D. S. 1920.

35 cents

BETTY AUSTIN. No. 696. Hybrid Cactus. Rosy carmine with small amounts of yellow at the base and tips. A very pretty flower and the bushes make a handsome appearance in the garden, being continually covered with the bright colored blossoms. It also is a valuable commercial variety as the flowers keep a long time when cut and have good stems.

50 cents

BLACK BEAUTY. No. 580. Decorative. Darkest maroon, almost black. Medium size flowers of regular formation and with good stems. An old favorite and still much in demand.

35 cents

BOB PLEUSE. No. 157. Hybrid Cactus. Very dark red, almost maroon, tipped white. Large flowers, freely produced on dwarf bushes. A most attractive dahlia.

50 cents

BONNIE BLUE. No. 112. Show. This is one of the most popular show dahlias we have ever grown. A striking feature is the near blue color, which so nicely blends with almost any other. The form is perfect, keeping quality when cut is good; in fact it is an all purpose dahlia. The size is modium, giving it a great variety of uses.

35 cents 


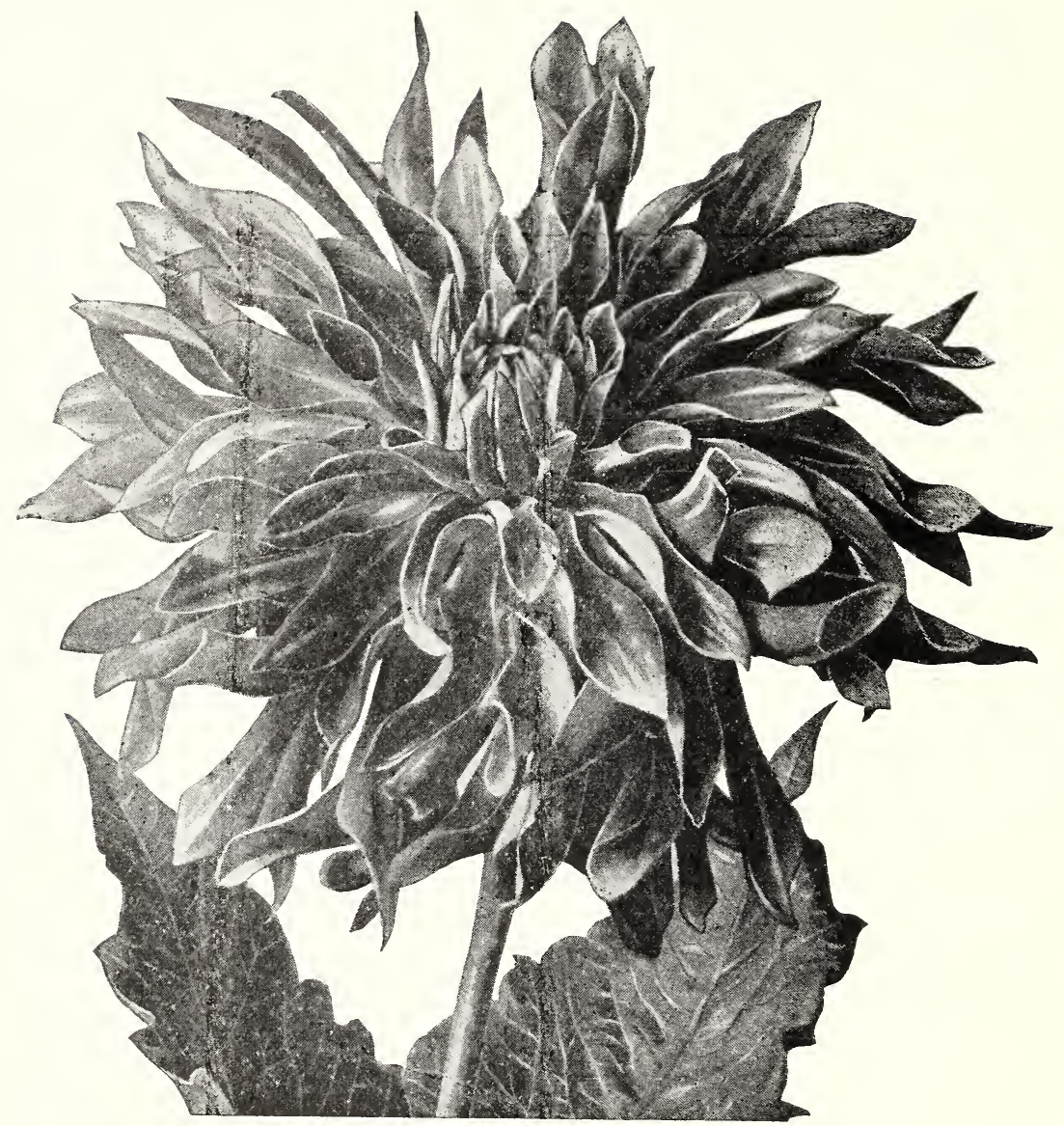

HYBRID CACTUS TYPE

BORDER PERFECTION. No. 841. Decorative. Bright scarlet red. This is a 1923 introduction from Holland and is one of the finest decoratives we have had from there. The immense flowers are of a very regular formation, with perfect centers and are carried upright on long rigid stems. The bush is of rather dwarf growth, making it a most desirable dahlia for garden use as well as for exhibition. Received the Award of Merit at the Holland Trials in 1922, First Class Certificate at Amsterdam and Haarlem in 1923 and the Award of Merit at Wisley, England in 1925.

$\$ 1.00$

B. P. O. E. No. 764. Hybrid Show. A California introduction which has been named in honor of the Benevolent and Protective Order of Elks because of its color, a rich regal purple. It makes a striking decoration, particularly when used with white dahlias of a similar type. The flowers are absolutely perfect in form, with the best of stems and keeping qualities.

35 cents 
CHAMPAGNE. No. 747. Decorative. A chamois color more or less tinted with a coppery brown, giving it the appearance of a rather pale: autumn shade. This dahlia has met with remarkable success: everywhere as it seems to be adapted to all climates. The flowers can be grown to a huge size and are held rigidly upright on strong stems.

$\$ 1.00$

CLARA SEATON. No. 224. Show. Rich golden bronze. The nearly ball-shaped flowers are large and perfectly shaped for this type.. The bush is a robust grower and is continually in bloom.

50 cents.

CLOTHILDE. No. 840. Decorative. Clean picric yellow. Large flowers formed by many wavy petals, giving them an appearance approaching the hybrid cactus type. It has a marked resemblance to the old Yellow King but it is a much more dependable grower. The bushes are rather low growing, but the stems are long and erect. Received an Award of Merit at Amsterdam and Utrecht in 1920, also at the Holland Trials in 1922; and a First Class Certificate at Haarlem in 1922.

50 cents

COCARDE. No. 185. Miniature Decorative. Flaming orange scarlet. A fine little flower from Holland, and very much in demand for cutting.

50 cents

CONQUEST. No. 263. Cactus. Dark blood red. A finely shaped dark colored flower of the true English type, with stems: as good as the average.

50 cents:

COPPER. No. 153. Peony. Very free in bloom, measuring from six. to ten inches in diameter; a profusion of copper colored blossoms, shaded and tinted with bronze and apricot, with, at times, a suggestion of salmon pink. The petals are broad and fluffy, twisted and often incurved; the bloom is carried well above the foliage, on strong, stiff stems. 35 cents

COURONNE d'OR. No. 13. Decorative. Old gold with an old rose reverse, giving a most effective color combination, the old rose on the reverse shows through the varying shades of gold, and as the petals twist it reflects itself to the face of the flower in a most charming way. The flowers are very large and very deep, perfectly double and are carried on long, stiff stems; they can be cut three feet long with very little: disbudding. The bushes are compact, grow about average height and produce an abundance of flowers througliout the season. This is one of: the: finest dahlias we have ever received from Europe, and has been most popular wherever grown.

$\$ 1.50$

DADDY BUTLER. No. 763. Hybrid Cactus. A peculiar dark shade of a rosy maroon with a lighter tint on the-reverse of the petals; this gives the flower a bi-colored effect as the petals curl. The large flowers are produced freely on bushes of medium height and keep most excellently when cut.

75 cents

DAYBREAK. No. 302. Peony Decorative. A sparkling white with the center faintly tinted a delicate shade of blush pink. An ideal dahlia for garden or cutting; the flowers are rather flat, with twisted petals and are borne freely on long wiry stems. This variety has been catalogued under the name of "Madonna" by some growers.

50. cents

DELI. No. 843. Decorative. A most attractive shading of fawn on the outside petals, gradually deepening to a rich copper at the very full center. This variety is one of our recent importations from Holland and we consider it a most valuable addition to our collection. The flowers are large and very solid, and have a substantial appearance, distinct from the usual type. The bushes make a heavy growth of foliage with unusually long: stems, which are stro. g and erect but not thick.

50 cents 
DELICE. No. 41. D̄ecorative. Clear pink. Has been used more by florists than probably any other dahlia and is the standard to which all other pink shades are compared. Its great charm is the clear bright color, which is without a trace of foreign shade; this, together with its medium size and exceptionally long keeping qualities, makes it adaptable to any floral work.

35 cents

DORA FISHER. No. 598. Collarette. Pink with a white collar. One of the most satisfactory of this popular type; the flowers are of medium size with the best of stems, and the contrasting shades of the pleasing pink petals with the white collar make it an ideal variety for commercial use.

50 cents

DUNDEE. No. 119. Hybrid Cactus. A rich shade of burnt orange. This variety was introduced several years ago but the stock of it has never been plentiful because of the demand for it by florists and commercial growers of cut flowers. The flowers are of medium size and are produced in great abundance on rather dwarf bushes. The stems are stiff and wiry. Its beautiful coloring, good keeping qualities and freedom in bloom make it one of the most useful dahlias for commercial growing.

50 cents

EAGLE. No. 599. Hybrid Cactus. Sulphur yellow. The large flowers are made up of many wavy petals, giving them the appearance of a large chrysanthemum, and keep well after cutting. The stems are long and erect.

50 cents

EARLE WILLIAMS. No. 704. Decorative. A mixture of red and white, with the red predominating. This variety has been very popular since its introduction several years ago because of the bizarre coloring of the flowers together with their perfect shape and large size. Unlike most bi-colored sorts very few of the flowers come in solid color but can be depended upon to be nearly all true. The stems are excellent. $\$ 1.00$

E. F. HAWES. No. 851. Cactus. One of the first of the true English cactus type of dahlia to come out which has a good stem. The color is a clear shade of pink which is most attractive. The flowers are large, perfectly shaped and have stems which compare favorably with any. 50 cents

EL CAMINO REAL. No. 362. Decorative. A gorgeous velvety Spanish crimson. A plant of this dahlia makes a most imposing showing in the garden; the large and full flowers above the heavy growth of dark green foliage give it an appearance of truly regal beauty. There has always been a heavy demand for this variety and we grow a large stock of it every season.

50 cents

EL GRANADA. No. 850. Hybrid Cactus. A monster dahlia in a truly sensational coloring, being a bright orange with a creamy yellow reverse which gives the flower a variable appearance as the petals twist and curl, and it really must be seen to have the full effect truly appreciated. The blossoms are among the very largest, very full and double, with good stems, and are borne well out of the handsome foliage.

$\$ 1.00$

ELIZA CLARK BULL. No. 61. Decorative. Pure white. A very large flower which has become very popular among Eastern growers, and is claimed to be the best white of any type. The flowers grow to an immense size and depth, and are produced freely on bushes of medium height. 
ELIZABETH PAPE. No. 634. Miniature Hybrid Cactus. A small flower of a pleasing shade of rosy salmon. This is one of the most profuse bloomers as the low growing bushes are literally covered with flowers for the entire season. Of great value for cutting and garden decoration.

50 cents

ELLINOR VAN DE VEER. No. 33. Decorative. Glowing rose pink. Large blooms of a perfectly regular formation carried high on stiff strong stems. Early to flower and very desirable. $\$ 1.00$

ELSA. No. 55. Peony. Pure white. This is an old variety but we still consider it to be one of the very best white dahlias we have. It is liable to come with a full center, especially so in the early part of the season when it may be classed with the decorative types. But in either shape it is satisfactory in every way. The color is clean, the flowers large, stems good and strong and an abundant bloomer. As a cut flower it ranks with the best.

50 cents

EMMA GROOT. No. 844. Decorative. This is one of the best of the recent foreign novelties as it is a distinctly new type of dahlia; a very large, rather flat flower, with big, broad and somewhat wavy petals, and stays perfect and fully double from the first to the last of the season. The color is a taking shade of deep mauve or lilac, which is very attractive anywhere, either in the day time or under artificial light. The stems are long and stiff as canes, but are not clumsy, and the flowers are carried way up above the bushes. Received an Award of Merit at the Holland Trials in 1923, a First Class Certificate at Amsterdam and Haarlem in 1924 and an Award of Merit at Wisley, England, in 1925. \$1.00

EMMA MARIE. No. 23. Decorative. Clear pink with a creamy white center. This variety is listed as a hybrid cactus by the introducer but almost always comes in the decorative type with us, as only occasionally do the back petals have a tendency to roll. This delicately colored dahlia is a prime favorite for both exhibition and commercial use; the flowers are large, keep a long time when eut and may be grown with three foot stems without any trouble.

$\$ 1.00$

EMPRESS EUGENIE. No. 585. Decorative. The impression you get when you see this flower is a wonderful rich lavender but the color chart gives it as a light rosolane purple shading to a light mallow purple. We have never seen a lavender dahlia that will make as many good flowers and keep as well when cut as this; it is nothing unusual for them to keep a week. It is in great demand by the florists on account of the popular color and the small wiry stems. It blooms early and keeps up throughout the season. Being a constant bloomer it is attractive in the garden. We recommend it most highly. C'ertificate of Merit A. D. S. 1921. 35 cents

FIREBRAND. No. 204. Decorative. Orange carmine. Very conspicuous because of the striking brilliant color. A flower of medium size and exceptionally fine stems; fine for cutting.

50 cents

FLAMING METEOR. No. 28. Decorative. Flaming orange scarlet. This new California variety has been a striking feature at all the recent local shows and is attracting much attention in the East as well as in Europe. It is a wonderful cut flower, with the best of keeping qualities and on long cane like stems. The large blooms with their brilliant coloring make it desirable for any purpose.

$\$ 2.50$

FLORRIE WELLS. No. 649. Cactus. Brilliant rosy crimson of the true English type. The stems are exceptionally good and the flowers very freely produced. 
FRANK SMITH. No. 83. Show. A rich dark maroon, tipped with white. This is probably the oldest dahlia in cultivation today. Professor Norton in his "7000 Dahlias" records it as being introduced in 1872 . A dahlia must have considerable merit to retain popularity for over fifty years in competition with the thousands which have been brought out (and also forgotten) in that time.

50 cents

GARDEN LOVE. No. 190. Miniature Decorative. Jasper red with a distinct golden yellow base. Small flowers very much resembling the new type of zinnias.

50 cents

GENERAL HAIG. No. 131. Show. Scarlet red. A new variety and probably the best of its color. The flowers are beautifully quilled and are perfect for exhibition use.

50 cents

GENERAL McRAE. No. 17. Decorative. Apricot suffused with old gold with reverse of petals in reddish salmon. A very large flower of most perfect form, held erect on long stiff stems. The petals are numerous and somewhat inclined to a quilled form; the centers stay double until way late in the season.

50 cents

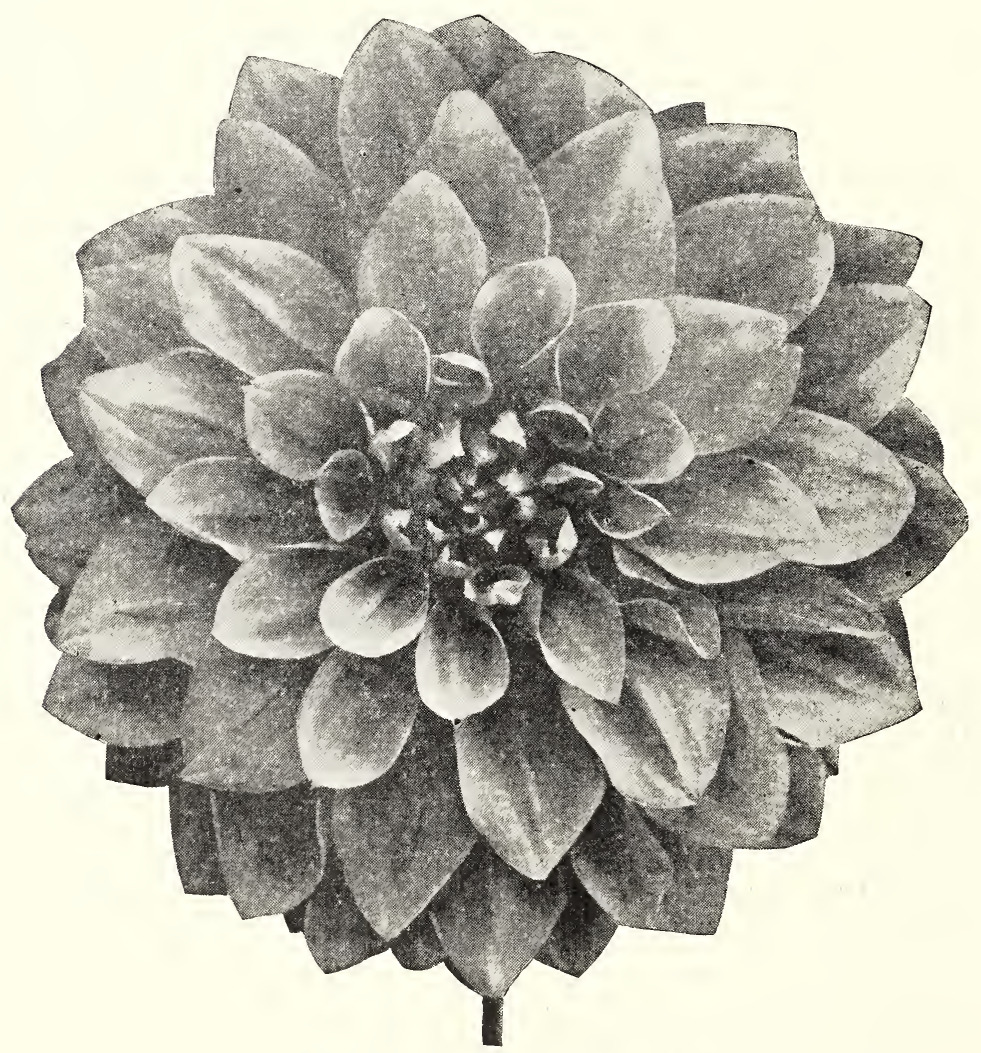

DECORATIVE TYPE 
GENERAL ROSALIE JONES. No. 237. Hybrid Cactus. Golden yellow. This is by far the best of the older dahlias of this type in a pure yellow and is surpassed by very few of the high priced newer kinds. The flowers are perfectly shaped, with full centers, are large and have good straight stems. Satisfactory for any purpose.

50 cents

GeORge WALTERS. No. 274. Hyörid Cactus. Pinkish salmon, tinged with gold at the center. This has always been one of the most popular dahlias since its introduction and it used to be the saying "if you grow only one dahlia, grow George Walters." It can be grown to enormous size and has been awarded many prizes for the largest dahlia exhibited at many shows. The coloring is very attractive, the shape almost perfect and the stems fine. We have always grown a large stock of this variety, but the unusual demand during the past two seasons reduced our planting to a very limited quantity.

50 cents

GLADYS BATES. No. 197. Cactus. The color is tan with the reverse of the petals rose colored and as the petals roll and twist both colors show, making a really attractive flower. The stem is especially good, which is appreciated in a cactus type. The blooming habit is profuse, making it a good variety for cutting. In fact it has all the good points a dahlia should have.

50 cents

GLORY OF AALSMEER. No. 676. Decorative. Pure white. This is an outstanding dahlia for cut flower purposes, as the stems and keeping qualities are of the best. The flowers are medium in size, of a very regular formation somewhat inclined to the ball-shape, and are produced in great quantities throughout the season.

50 cents

GOLDEN COLLAR. No. 303. Collarette. Clear lemon yellow with collar of just the same shade. This new collarette is practically perfect in every way. The color is clean and pure without a tinge of green, the center when fully developed is a deep chrome and contrasts wonderfully well with the petals. The flowers are of large size and are held straight up on long stems that are as rigid as the best of any of the other types, and keep for a long time when cut.

$\$ 1.00$

GOLDEN RULE. No. 44. Decorative. Clean lemon yellow, shading to a golden center without the slightest tinge of green. This is another perfect yellow dahlia, but of a decidedly different type than our Gold Rush. The flowers are large, with rounded shell-shaped petals, resembling water lilies, and are of such firm texture that they well withstand the summer's heat, keeping a long time when cut. The stems are long and stiff, and the flowers are held erect after the style of the new Holland types. The bushes are tall with heavy substantial foliage and bloom freely. We consider this new dahlia to be the best in its type and color and do not hesitate to recommend it for any purpose.

$\$ 2.50$

GOLDEN WEST. No. 6. Hybrid Cactus. Deep rich yellow heavily overlaid with orange. This is the old stand-by for cut flowers. 50 cents

GOLD RUSH. No. 87. Decorative. Clear lemon yellow. We introduced this variety three years ago as a nearly pefect dahlia of its type and color, and the reports from our customers who have grown it indicate that this is true, because it has been a success everywhere it has been grown. It is a 1920 seedling from Copper, but has no resemblance to the parent in any respect. The flowers are large, but not particularly immense, in a true, regular decorative type, with full centers to the end of the season, and of a clear deep lemon yellow without a tinge of green. The bush is a vigorous grower of average height and is particularly striking in the garden because of the sharp contrast between the quantities 
of yellow blooms rising well up above the heavy dark green foliage. The flowers keep a long time when cut and are carried upright on the best of stems. Our stock of it this season is ample to take care of all reasonable demands, so we are able to offer it at a very moderate price. 75 cents

GUSHER. No. 1. Hybrid Cactus. Deep scarlet red, but some of the flowers may come in a tawny orange. This trait is inherited from Gustav Doazon, of which it is a seedling. The flowers are of an attractive shaggy formation and may be grown to an immense size and depth, making it a wonderful exhibition variety; it is also fine for garden use as the bright colored blossoms are produced very freely. Certificate of Merit A. D. S., 1923.

50 cents

GUSTAV DOAZON. No. 52. Decorative. Red. One of the old standby dahlias that always comes good and large; a free bloomer, keeps well when cut and has always been most popular ever since its introduction several years ago.

35 cents.

GYPSY MAID. No. 89. Decorative. Bright rose. A strikingly beautiful dahlia particularly suited for cutting. The flowers are not overly large, are of an attractive formation with perfect centers and the outer petals inclined to be quilled and pointed. The bushes are of medium height and carry the flowel's erect and upright on thin wiry stems. The great beauty of the flowers is the brilliant rich rose color which looms up equally well in artificial light as well as in daylight.

50 cents

HANNY VAN WAVEREN. No. 817. Decorative. Delicate amaranth pink, shading to a darker center. A beautiful new Holland variety of a distinct shade. The flower's are rather flat, with full centers and are freely produced on stiff cane-like stems. Received a First Class C'ertificate at the Holland Trials in 1921 and was given an Award of Merit at Wisley, England, and also at Haarlem, in 1922.

50 cents

HEIMWEH. No. 847. Hybrid Cactus. Brilliant amaranth purple with yellow at the base of the petals; this shows up as a distinct narrow yellow ring around the unopened center. The flowers are large and are made up of nearly tubular petals, regularly arranged, and are of a solid and very formal appearance, with the best of stems and excellent keeping qualities. The bushes grow to a medium height with a profusion of blooms throughout the season, making a most attractive show in the garden. This variety is one of the best of the recent German introductions and will take its place as a general all-purpose dahlia. 50 cents

HELIUM. No. 647. Hybrid Cactus. The color combination is a heavy layer of cadmium orange over a chrome yellow. This variety was ol'lginated by Mr. P. A. Vincent, of Santa Barbara, in 1920 from seed of Golden West. It somewhat resembles the parent in size and shape but is a much more showy flower because of the brilliant combination of contrasting colors. The bush grows tall and produees plenty of flowers on long, stiff stems.

50 cents

HERMIONE. No. 154. Decorative. Golden yellow, uniformly tinted with orange red, giving an appearance from a distance of light orange. The color resembles the old show variety Gold Medal, but the shape is decidedly different, being a ball-shaped decorative, only approaching the hybrid show type. This is primarily a cut flower dahlia and as such, has all the requirements; good stems, attractive coloring, fair size and, above all, is a remarkable keeper.

50 cents

IMP. No. 564. Cactus. Very dark maroon. This is a nearly black flower of a perfectly incurved type of English cactus; the claw shaped 
petals, as they twist and bend inward, give it the appearance of a big black spider. Has always been very popular and much in demand. 50 cents

INDIAN NECK. No. 514. Decorative. Cameo pink, striped with pomegranate purple. This is a really magnificent dahlia of recent introduction which has not received the popularity it should have, as it is superior in many ways to some of those which are now in the height of public favor. The judges of the American Dahlia Society gave it a Certificate of Merit with one of the highest scores, and after our experience with it during the past several seasons, we know that the distinction was fully justified. The coloring is most pleasing, the flowers are large, with perfect stems, and are produced in great quantities the whole season through.

$\$ 1.00$

INSULINDE. No. 372. Decorative. Bronzy yellow, shading to a russet orange. This recent Holland dahlia has proved to be one of the finest yet brought out and is becoming more and more popular every year. The color is one of those striking combinations of autumn tints which everyone admires and the form of the blossoms is perfect; tho broad wavy petals curl and twist so that the different shades give an irresistible effect. The large flowers are carried straight across on magnificent stems and keep for a long time when cut. We consider it one of the best dahlias in cultivation today regardless of price. $\$ 1.00$

ISLAM PATROL. No. 571. Decorative. Deep scarlet, tipped and flushed with gold. One of the most striking and satisfactory dahlias we have, but the stock is never plentiful owing to the fact that the bushes do not make many roots. The plants grow tall and heavy, with extra good stems, and the large flowers keep exceptionally well when cut. $\$ 1.50$

JACK LONDON. No. 823. Decorative. Spectrum red. This is quite an old variety but has never become very well known although it is one of the most meritorious in our collection. The flowers ara large, of the brightest and most pleasing red, abundantly produced on the best of stems. The color is so striking that the bushes attract the attention at first glance.

50 cents

JEAN CHAZOT. (Gay Paree) No. 252. Hybrid Cactus. Capucine or nasturtium red with a golden suffusion, frequently tipped with golden yellow. A recent French introduction which we consider as one of the finest autumn colored cactus varities for cutting and also for mass planting. The flowers are of good size, very graceful formation, held lip on long, stiff stems in such a manner that they show the full flower to the best advantage.

75 cents

JEAN FAREAUX. No. 68. Decorative. Red and yellow. Medium size flowers, with extra good stems, very bright and fine for cutting.

50 cents

JEAN KERR. No. 391. Decorative. Pure white. A ball shaped flower closely resembling the hybrid show type. It is one of the most reliable dahlias, blooming under most adverse conditions, regardless of the weather. The pure white blooms are carried gracefully on long and stiff stems well above the foliage and are particularly well adapted for cut flower purposes.

50 cents

JERSEY'S BEACON. No. 184. Decorative. Tawny scarlet with a lighter reverse. This is a very large, and deep, shaggy dahlia, and, as the petals twist, a beautiful two-tone effect is produced. The bushes are strong and vigorous growers with excellent stems. Desirable in every way.

$\$ 1.00$ 
JERSEY'S BEAUTY, No. 103. Decorative. Clear pure pink. This dahlia has been so well advertised by its extra good qualities that it really needs very little description. It is one of few outstanding varieties, and has become most popular all over the world. The flowers are large, of a perfect formation and continue so throughout the season; the bushes grow extra tall and stems may be had of almost any length. One of the very best and should be in every garden.

$\$ 1.00$

JERSEY'S JEWEL. No. 37. Decorative. Mallow pink underlaid with a creamy white. A fine exhibition variety of the largest size and on good stems. The flowers are made up of many long and somewhat wavy petals, and, although they appear delicate, are really very substantial and stand up fine when cut.

50 cents

JEWEELTJE. (Little Jewel). No. 819. Miniature Decorative. Light pink. In this dainty little flower we have an entirely new type of dahlia; one of the large California growers after seeing it in Europe writes, "It is one of the best novelties in the dahlia field and about the only variety which is distinct in the recent introductions." The blooms are a clear pink, just about the shade of Delice and will average two or two and onehalf inches across. The stems are thin, but strong and wiry, and the bushes are continually covered with flowers. Because of the small size and beautiful shade of pink it can be used in many places where cther dahlias may not be suitable. This variety will be in great demand for commercial growing and should be also grown in every home garden.

50 cents

J. H. JACKSON. No. 115 Cactus. A gorgeous, velvety, blackish maroon. A really beautiful dark colored dahlia useful for any purpose; a prominent garden variety, fine for cutting and superb for exhibition.

35 cents

JOHAN MENSING. No. 10. Decorative. Deep scarlet crimson. A ball-shaped flower of medium size with rigid and upright stems; its exceptionally good keeping qualities make it a desirable variety for cut flower purposes.

35 cents

JOHN LEWIS CHILDS. No. 366. Decorative. One of our very best fancy or multi-colored dahlias, the ground work being yellow, splashed and striped with a brilliant scarlet, and often showing a decided amount of white, which is usually at the tips. The gayly colored flowers are large and deep, perfectly double and are grown on good strong stems. 'This variety does not produce many flowers of a solid color, like many of the vari-colored ones do, but it can be depended upon to give a profusion of the mottled blooms the season through.

$\$ 1.00$

JOHN RIDING. No. 177. Cactus. This is a very beautiful scarlet maroon, incurved English cactus type. A dwarf grower and is constantly covered with a great profusion of these bright flowers. Stem is slightly pendant, making a good flower for use in baskets for home decorations. Our stock of it is never enough to supply the demand.

50 cents

J. W. DAVIES. No. 581. Decorative. A distinct and novel coloring which is hard to picture; the originator gives it as a "deepest shade of cerise at the center, graduating to a lighter tint, the blending of two shades of cerise creates an entirely new effect." This dahlia has been grown to an enormous size, very full and deep, and keeps its size and shape the season through; the stems are good and strong with sufficient length to bring the blooms well up above medium size bushes. $\$ 1.00$ 
KING HAROLD. No. 848. Peony Decorative. Very dark maroon. The dark colored dahlias have always been very popular because of the rich velvety appearance, but most of these, especially in the peony class, have not liad sufficiently strong stems. In this new Holland variety we have one which is satisfactory in every way: large size, rich coloring and good stems. The flowers first come out as a loose decorative and change to the peony type as the season advances. The color is almost a velvety black and makes a striking decoration when used with any of the shades of pink.

50 cents

KISSIMEE. No. 743. Decorative, but may almost be classed as a hybrid show, the flowers having the appearance of large balls with cupped petals, which bend back nearly to the stem, the centers are full and perfect. The color is a beautiful combination of yellow, gold and ochre with a distinct pink shading on the reverse side which contrasts as the petals reflex back. This is really a distinct novelty.

35 cents.

KITTIE DUNLAP. No. 745. Decorative. A new shade resembling the American Beauty rose. This is one of the most satisfactory and dependable dahlias for any purpose, exhibition, cutting or garden. The flowers are freely produced all season; are of large size and keep exceptionally well when cut; the petals are broad with a slight tendency to roll; and the long stiff stems are practically without leaves. It is a vigorous grower under all conditions of weather or soil.

50 cents

LA DOSKA DOWD. No. 666. Decorative. This is one of our 1924 intrcductions which is rapidly becoming recognized as a standard cut flower variety. The color is a clear yellow and is enhanced by a rich golden center. The large flowers are produced very freely on long thin stems, but of sufficient rigidity to hold them erect. Certificate of Merit A. D. S., 1923.

35 cents

LE GRAND MANITOU. No. 248. Decorative. White heavily streaked and speckled with purple, giving a general effect of grayish lavender. One of the favorites and still in great demand. However, like all varigated dahlias, the flowers often come in solid colors. 50 cents

LILLIAN VAN MARTER. No. 149. Decorative. Deep lilac. One of the most perfect, large size decoratives in our collection and satisfactory in every way. The bushes are of medium height with long straight stems. It was introduced by Robert DuBois in 1925.

$\$ 1.00$

MME. JULES GALBAN. No. 845. Hybrid Cactus. In this French novelty we have an entirely new shape in dahlias; the flowers are very solid and deep, made up. of so many quilled petals that they resemble a huge chrysanthemum in shape and size. The coloring is a mixture of a bright reddish orange, golden yellow and white, some flowers showing all three colors, others only two and some even come in a solid color, and all may be on the same bush. The plants grow to medium height and the stems are exceptionally stiff.

50 cents

MAHOGANY. No. 9. Hybrid Cactus. Dark rich red, many of the petals being veined with ox-blood red. The very large flowers are carried erect on long stiff stems, and do not burn in hot weather.

$\$ 1.00$

MARIPOSA. No. 108. Hybrid Cactus. Clear shade of lavender pink intensified by the full and dark center. This is one of the most popular California novelties of gigantic size and depth; the perfect flowers are formed of many long incurved petals which turn and twist in such a way as to create an impression of shaggy hugeness. With us, near the ocean, the color is a brilliant pink, but in hot locations it comes somewhat lighter. The stems are exceptionally long and stiff and plants start to bloom early and continue to produce great quantities of flowers until the ena of the season. 


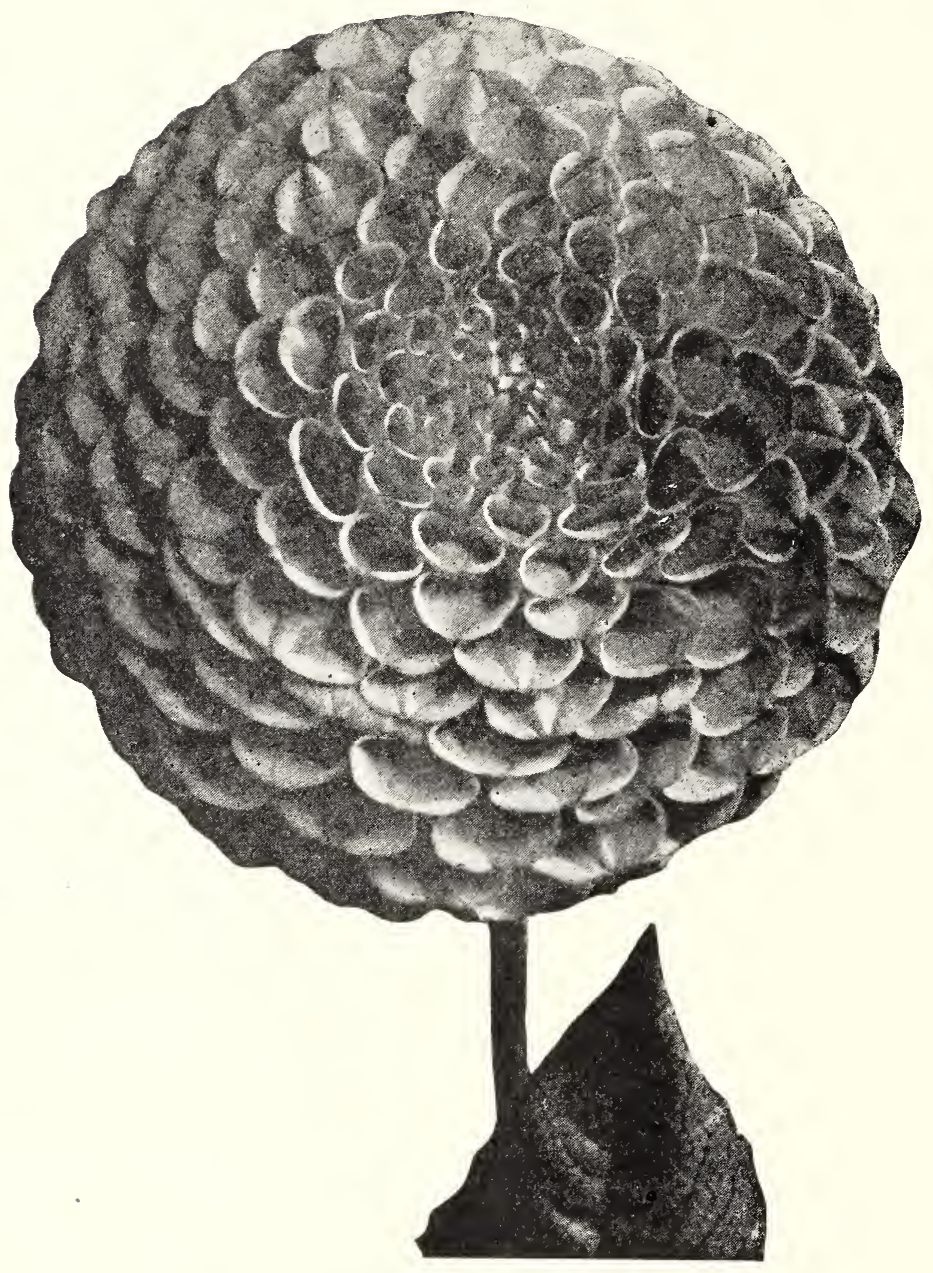

SHOW TYPE

MARY AUGUSTA. No. 288. Peony. Jasper pink shading to light jasper red, with chrome yellow veining. The flowers are fairly large, with several rows of petals and a clean yellow center. This is really an excellent cut flower on account of its good keeping qualities and especially stiff erect stems.

50 cents

MARY PURRIER. No. 221. Cactus. Bright red. Although this variety has been known for some fifteen years or more it is still considered to be among the best of the true English type of castus dahlias. The flowers are of a beautiful wavy formation, immense in size and with good stems.

$\$ 1.00$ 
MAUDE ADAMS. No. 331. Show. Snowy white, faintly tipped with pale pink, making a most dainty looking flower. This coloring together with the perfect stems and keeping qualities make it an ideal flower for cutting.

35 cents.

MEPHISTOPHELES. No. 662. Decorative. Ruby red with small golden yellow points at the very tips of some of the petals, which greatly enhance the beauty of the large flowers. This is a real aristocrat among dahlias and it is an attraction at every show where exhibited. But it is in the garden where it really shows off to best advantage; although the flowers are big, great quantities of them are produced on unusually strong stems which hold them up erect and unbending high above a plant of ex. traordinary vigor.

50 cents

MEVROUW BALLEGO. No. 280. Hybrid Cactus. Brilliant garnet with scarlet shadings. The rather broad, more or less fluted petals form a large, showy flower of a rather informal shape, but which is very attractive. The stems are stiff and erect, supporting the flowers so as to show their full beauty; very free blooming.

50 cents

MILLIONAIRE. No. 186. Decorative. Lavender, over-shadowed with a pink cast. This is a monster dahlia and can easily be grown to prize winning size. The flowers stand erect on strong stems and last a long time when cut.

50 cents

MINA BURGLE. No. 24. Decorative. Pure red. This was the first dahlia of California origin to attract national attention, and now, after fifteen years, it is still the outstanding red for cut flower use. 35 cents

MISS ATLANTIC CITY. No. 30. Decorative. Lilac rose with a distinct golden yellow center. This is one of the best of the newer dahlias for cut flower work, because the bushes grow symmetrical without any cutting back and the flowers come on long, stiff and wiry stems with a minimum amount of disbudding. The petals are long and pointed, making a most artistic flower of a wavy formation inclining to the hybrid cactus type.

$\$ 1.00$

MISS HELEN HOLLIS. No. 317. Show. Deep scarlet. Another one of the largest dahlias in this type and with long and perrect stems. 50 cents

MR. H. C. DRESSELHUYS. No. 677. Decorative. Light pink with a little white or blush suffusion. Similar to Delice, but is somewhat lighter and a much more free bloomer. The stems are extra long and erect, with flowers of remarkable keeping qualities. Received a Certificate of Merit from The American Dahlia Society, both at Storrs and at the Southern Trial Gardens, and has also been awarded various prizes at the different trial gardens in England, France and Holland.

50 cents

MRS. ALFRED STERN. No. 34. Hybrid Cactus. A large lavender pink flower made up of many narrow petals with serrated tips, giving it the appearance of a big, fully double poppy. The blossoms are of medium size, produced in large quantities on rather low bushes. Has been a long tinie favorite and is very popular as a cut flower.

35 cents

MRS. C. A. GILLAT. No. 45. Cactus. Rose pink, blending to a golden yellow center. A fine type of the true English cactus, which may be grown to very large size. As usual with the cactus varieties the stems are not particularly strong, however the flowers are especially good for exhibition purposes. 
MRS. CARL SALBACH. No. 49. Decorative. Mauve or mallow pink. A reliable cut flower sort, the flowers being abundantly produced on long stiff stems.

50 cents

MRS. ESTELLE LAWTON LINDSAY. No. 758. Decorative. Tawny scarlet and gold; the scarlet predominates in most of the flowers, but in some more of the golden yellow shows. This is an immense brightly colored decorative which attracts attention at once. The stems are strong and erect, and the flowers keep well when cut.

$\$ 1.00$

MRS. ETHEL F. T. SMITH. No. 638. Hybrid Cactus. Creamy white, shading to a lemon in the center. It is a profuse bloomer, the flowers grow to an immense size without disbudding and are held far above the foliage on strong stems. This variety wins the admiration of all visitors to our gardens and is also particularly useful for exhibition, as it has won several prizes at different shows for size.

50 cents

MRS. I. De Ver WARNER. No. 754. Decorative. One of the best known of the Marean introductions and it is truly a remarkable dahlia. The flowers grow to an immense size without any great amount of disbudding, are of a perfect regular type and in the most glowing shade of mauve pink. The plants are tall, vigorous growers, and start giving flowers early in the season and continue to produce quantities of them until the end. This variety has been a success wherever grown and is among the most popular in our gardens.

50 cents

MRS. JACK GREEN. No. 51. Decorative... Brilliant light red, a shade most distinctive and attractive in the garden, especially in this variety, because the long stems hold the many bright flowers high above the foliage.

50 cents

MRS. J. HARRISON DICK. No. 857. Decorative. Creamy yellow at the center, gradually shading to a salmon pink on the outer petals. A fine variety for cutting purposes, as it is an exceptionally free bloomer, with good stems and the flowers keep a long time.

35 cents

MRS. JOHN BAZANT. No. 281. Decorative. Nearly white, blending to very faint canary yellow at the center. Good white dahlias, suitable for cut flower purposes, are not any too numerous; and in this new variety we have a decided acquisition to these, as well as a fine exhibition flower. The blossoms are of a loose, wavy formarion, and are perfectly double to the end of the season. Although not a pure white, it may be used for any purpose where white flowers are needed, as there is just enough of the faint yellow shading to relieve the deadness of a clear white; and the slight tinge of color really enhances the beauty of the bloom. The flowers keep a long time after cutting and are produced very freely with erect, wiry stems on bushes of medium height. 50 cents

MRS. O. M. COURAGE. No. 732. Collarette. A new English variety. Deep carmine, shading to a lighter edge and a white collar. Grows with good straight stems and is especially suited for basket work. 35 cents

MRS. P. A. VINCENT. No. 828. Hybrid Cactus. Apricot buff. This variety was first shown in a limited way under the name of "Rosy Morn" by P. A. Vincent, of Santa Barbara, who is the originator, and created quite a furore in that locality, where practically every dahlia in commerce today is known and grown; it was later re-named in honor of his wife. The large flowers are of a glowing apricot buff, of perfect shape and produced very freely on perfect stems; a remarkable cut flower.

50 cents 
MONTECITO. No. 133. Hybrid Cactus. Coral pink, blending to yellow at the base of the petals. This variety is particularly valuable as a cut flower and will become one of the standard commercial sorts when better known. The flowers are fairly large, averaging five or six inches across, with good depth and substance and have the best of stems. Received Certificate of Merit at the A. D. S. Trials in 1923, both as a commercial and an exhibition flower.

$\$ 1.00$

MOUNT EVEREST. No. 837. Decorative. Pure white. A large regular type blcom which stands well up above the foliage on long and strong stems; well suited for cut flower purposes. First Class Certificate at Haarlem, 1922.

50 cents

NANON LOUISE. No. 14. Cactus. Amaranth pink. This new cactus dahlia was developed in the gardens of Mr's. Evelyn M. Dane, of Los Angeles, and is probably the best one of her many seedlings. The flowers are made up of many tubular petals, like the true English cactus type, but the petals do not incurve; instead they spread out to make a flower of enormous size-10 or 11 inches without being forced. The stems are wiry and straight, holding the flower erect; the bushes are of medium height and bloom continually throughout the season. We introduced this variety last season in a limited way, and several of our customers, both in the East and West, have reported it to be the best dahlia in their collection. Stock still rather limited.

$\$ 7.50$

NOBILIS. No. 417. Decorative. A beautiful combination of white and scarlet, with the white predominating. The large, bold flowers are carried on robust stems and keep exceptionally well after cutting. This variety is a sport from Earle Williams and differs from it only in the amount of red in the flowers. Both are nost desirable where really showy effects are wanted and both are grown successfully everywhere.

$\$ 1.00$

NORMAN. No. 416. Cactus. A cactus with every good quality; formation, stem, color, size and free flowering. The immense flower is composed of many exceedingly fine petals which give it great depth. The color is a fine scarlet. Good for cutting, exhibition or garden. 75 cents

ORANGE BOVEN. No. 818. Decorative. Fiery orange scarlet, one of the most attractive shades of this color. A new Holland variety of exceptional merit and one which will compare most favorably in every way with any of the recent novelties. The flowers are large, of the most perfect decorative type, very double and with full centers, and remain so throughout the entire season. The bushes grow to an average height and produce quantities of blossoms continually on ideal stems. Without doubt it will be in great demand by commercial growers when it becomes known in this country, as it has all the qualities required of a florists' dahlia. In 1921 it received a First Class Certificate at Amsterdam, an Award of Merit at Haarlem and also at the General Holland Trials, and in 1922 it was given an Award of Merit at Paris.

50 cents

ORANGE DOAZON. No. 72. Decorative. An exact counterpart of Gustav Doazon, from which it is a sport, and differs only in color. Some of the flowers may revert to the original red.

50 cents

PAGEANT BEAUTY. No. 40. Decorative. Deep golden orange. This new Eastern dahlia is exceptionally good for cutting purposes, as the flowers stand up better than most others, and are produced in great profusion on perfect stems. The flowers are large and of a loose wavy formation of the hybrid decorative type.

50 cents 


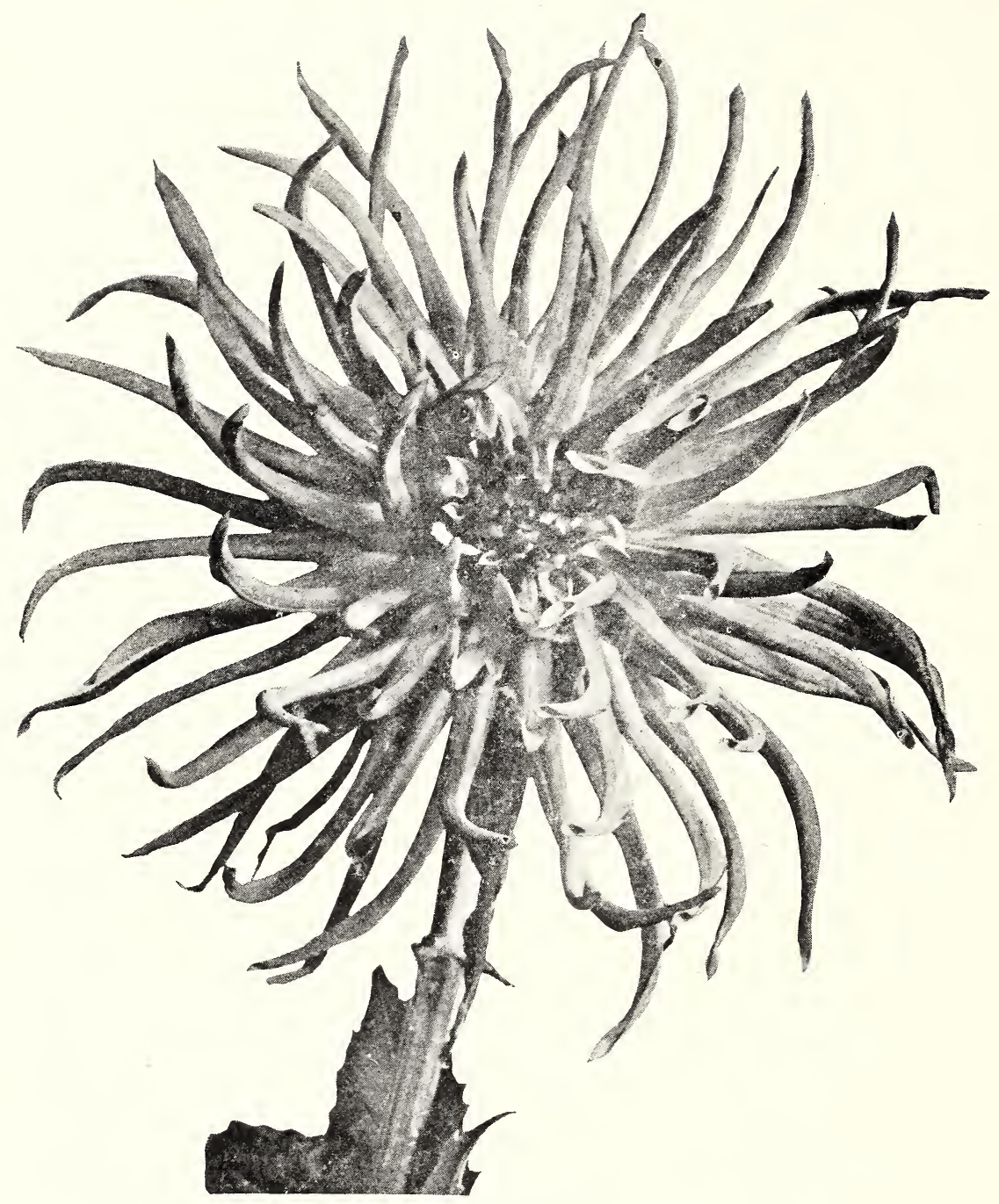

CACTUS TYPE

PAUL MICHAEL. No. 477. Decorative. This variety has been offered by some growers under the name of "California Gold". A deep orange bufi with a tinge of old rose on the reverse of the petals. The flowers are unexcelled for exhibition purposes as they grow to an immerce size, and the peculiar wavy and curled petals greatly enhance their beauty.

$\$ 1.00$

PINK FLAMINGo. No. 130. Peony. A clear rose pink of medium size on the best of stems; a perfect cut flower. The blooms often come decorative and are strikingly handsome in either type. 
PINK TRIUMPHANT. No. 604. Decorative. A 1923 California introduction which is primarily a strictly high class cut flower variety, because of its beautiful pink color and its wonderful keeping qualities when cut. It also is a very free bloomer and the flowers keep the full centers until cut down by frost. The stems are long and stiff, and hold the large blooms up erect, so you can look right into their faces. Received Certificate of Merit at the American Dahlia Society Trial Gardens in 1922, scoring the highest number of points of any dahlia for that year.

50 cents

PRIDE OF CALIFORNIA. No. 345. Decorative. Crimson red with a darker center. One of the older California dhalias, which has become recognized as a standard for any purpose. Every season large plantings are made of it for supplying the cut flower markets, and the demand for roots steadily continues. The flowers grow large, with fully closed centers, the best of stems and keep remarkably well after being cut.

35 cents

PRINCESS ALINE. No. 8. Decorative. Clear rosy pink, shading to a lighter edge. This is one of our 1927 introductions and we consider it to be one of the best dahlias for commercial use we have ever grown. The flowers are not particularly large, but are of a perfect ball-shaped formation, with slightly quilled petals somewhat resembling the hybrid show type; the centers are very full and remain so throughout the season. The coloring is a most pleasing shade of bright pink and looms up exquisitely under artificial light, making it very effective as a decoration either in the day time or at night. The petals are firm and solid, and the flowers keep fully as long as any variety in our collection, both on the bush or when cut; in fact they never seem to wilt, but rather drop the petals when they are old. The stems, of course, are perfect, and freedom in bloom and habit of the bush are all that can be desired. We can conscientiously recommend this new variety to all growers as an outstanding dahlia, either for home use or for commercial planting.

$\$ 1.00$

PRINCESS GERANE. No. 26. Decorative. Phlox pink shading to slightly darker at the outer edge of the petals, with the center of the flower a rich phlox purple. A solid and substantial flower of good size and a perfect regular formation inclined somewhat toward the hybrid show type. Its exceptionally good keeping qualities and fine stems make it an outstanding cut flower.

50 cents

PRINCESS PAT. No. 519. Decorative. A beautiful shade of old rose, deepening toward the center. The flowers are very large and always full to the center, the stems extra long and straight.

75 cents

QUEEN DIDO. No. 91. Decorative. A deep shade between Tyrian pink and mallow purple. One of our 1925 introductions and a most excellent all purpose dahlia, and a particularly good commercial sort-large flowers of a pleasing color, produced freely on long and erect stems.

50 cents

QUEEN MARY. No. 139. Decorative. A pale silvery pink which is used a great deal in the cut flower trade. The flowers are of medium size and produced abundantly on excellent stems. The keeping qualities are of the best.

35 cents

QUEEN OF THE GARDEN BEAUtiful. No. 2. Decorative. Pale lemon yellow. This is without doubt one of the largest of all dahlias, and can be grown to immense size without any special effort, even when grown with ordinary field culture. The habit of growth is unusually vigorous, with lieavy foliage and strong stems. It was awarded the Samuel W. Heller prize it the San Francisco Show in 1925, and has been a consistent prize winner as the largest dahlia in many shows the country over.

$\$ 2.50$ 
RALPH BALL. No. 589. Decorative. Deep yellow, shading to gold at ihe base of the petals. This is a seedling from Millionaire and is in every way worthy of its parentage. While the flowers do not grow to such a monstrous size as the Millionaire, they still are very large and always very full with good depth. The bushes are of average height, with a heavy growth of foliage and the stems are long and stout, carrying the blooms straight up. Certificate of Merit, A. D. S., 1922.

50 cents

RAPALLO. No. 195. Decorative. Oxblood red, tipped and edged with lemon yellow. This new Holland variety has been a sensation in Europe and especially so at the London shows during the past two years. The plants are rather low and the flowers of medium size, too large to be classed with the "miniatures"; but it is the striking color combination which at once attracts attention and admiration. Will become a popular cut flower when known.

$\$ 1.00$

RISING BEAUTY. No. 151. Hybrid Cactus Peony. Color is deep scarlet red, tipped and striped with yellow. Similar to Geisha in coloring, but the red is deeper, making the contrast greater. Usually grows as a hybrid cactus in our locality, but late in the season is inclined to the peony formation. We have now grown this variety for six seasons and the continued demand for it confirms our prediction that it would become one of the leading commercial sorts as its good qualities become known. It is one of the first to bloom, the bushes being continually covered with the large striking flowers; we have had it in flower from the fore part of July continually into December. The habit of the plant is most vigorous, the stems are long and rigid, and the flowers, being well placed on the stems stand high above the foliage. It is really one of the valuable additions to any collection of dahlias.

$\$ 1.50$

ROBERT TREAT. No. 111. Decorative. American Beauty rose. This is, without doubt, the best dahlia in this color and far outranks any other yet brought out. It has no faults; the flowers are immense in size and perfect in shape, the stems are ideal and the bushes grow to an average lieight. We consider it a real acquisition to any collection.

$\$ 1.00$

RODMAN WANAMAKER. No. 396. Decorative. Salmon pink with yellow center; the flowers first open a pale lemon yellow, but the outer petals quickly change to the salmon pink and when the flowers are fully mature they are practically all of the latter color. This is one of the largest and finest dahlias in our whole collection; can be grown to an immense size by forcing and disbudding, and with ordinary culture the flowers will be from eight to ten inches across. The bushes are strong and vigorous, with bright green partly cut foliage, and produce great quantities of huge flowers throughout the whole season. The stems are long and straight, making it a fine cut flower for commercial use, as well as for exhibition and the garden.

$\$ 2.00$

ROLANDO. No. 121. Collarette. Dark carmine, white collar. A very. desirable new collarette in most effective contrasts; the large heavy collar is slightly colored with carmine and surrounds a clear yellow center, back of this are the dark carmine petals with no trace of magenta. The flowers are large and firm, with long stiff stems, generously produced on medium size bushes.

50 cents

ROMAN EAGLE. No. 94. Decorative. Brilliant salmon orange, This is our own introduction of 1926 and the name was registered with the American Dahlia Society in 1920. The flowers are large, deep and full with wavy petals of good substance and remain in fine condition until the blooming season is over. The habit of growth is tall with plenty of large and heavy foliage. The stems are exceptionally strong, carrying an abundance of flowers way up in the air.

75 cents 
ROSA NELL. No. 529. Decorative. A deep bright rose, a most unusual shade in dahlias, makes this variety one of the most striking and popular of the newer introductions; is considered by its originator as "the greatest of all decorative dahlias". The gigantic blooms are always full to the center, freely produced on long stiff stms, and keep exceptionally well both on the bush and when cut.

50 cents

ROSE ELEGANCE. No. 213. Decorative. Bright rose, enhanced by golden yellow at the base of the petals. This is a very beautiful new cut fiower dahlia from Holland. The flowers are of medium size and a most attractive shade of rose, with stems of such length and stiffness that they may be cut two to three feet long with very little disbudding. 50 cents

SILVA QUARTA. No. 12. Show. Phlox pink. A big, perfectly ballshaped flower made up of rather large, quilied petals, and these are rather odd in that most of the tubes have two or three smaller petals inside, giving a most unique effect.

50 cents

SNOWDRIFT. No. 80. Hybrid Cactus. Pure white, of par excellence as a cut flower, large size, good stems, pure color and wonderful keeping qualities. This variety should not be confused with the decorative type of the same name.

50 cents

SUNSET GLOW. No. 54. Hybrid Cactus. This is one of our 1924 introductions, and was originated by Mr. P. A. Vincent, of Santa Barbara. The colors are in those desirable shades of shrimp pink, shading off to a yellow center. The flowers are very substantial, and are produced in the utmost freedom on rather dwarf bushes and and on perfect stems. Has been very successful as a commercial and exhibition flower.

50 cents

TARANTULA. No. 123. Cactus. This dahlia is very similar to the popular F. W. Fellows both in shape and coloring, but the roots keep better and are wintered more easily than the latter, which has always been a drawback to that most excellent variety. The large flowers are of a salmon orange, shading to a darker center.

50 cents

TOMMY ATKINS. No. 145. Decorative. Flaming scarlet. An extremely brilliant flower and a shade entirely different from any red dahlia which we have. The huge blooms are artistically made up of loose v-shaped petals and are continuously produced on the best of stems.

$\$ 1.00$

TRENTONIAN. No. 38. Decorative. A real autumn color most difficult to describe, and probably the nearest approach, according to Ridgway's standard, is a heavy layer of deep eugenia red over old gold; giving a general appearance like the hue of an Indian's skin. The effect is most striking and captivating because it is so different from any other dahlia. The individual flowers are of a perfect, broad petaled decorative type, and can be grown with ordinary culture to a huge size on three or four foot stems. A bouquet or basket of these leathery flowers is a wonderful sight and lasts for days. It is without doubt one of the outstanding dahlias of recent introduction.

75 cents

TRYPHINNIE. No. 643. Decorative. A most delightful combination of light and deep pink with golden yellow shadings at the base. This is another variety which has for some reason been overlooked in popular favor, but is now coming into its own. The immense flowers are perfection itself and the strong and upright stems carry them high above the bushes. We consider it one of the best dahlias and recommend it for any purpose.

50 cents 
U. S. A. No. 275. Hybrid Cactus. A glowing orange red. Has always been one of the most popular dahlias and still is a most desirable flower for either commercial or exhibition use.

VALENCIA. No. 95. Decorative. Chrome yellow with cadmium orange shadings. A 1920 seedling from C. C. Moore. The habit of this dahlia resembles that of some of the newer European productions, of which In. sulinde is probably the best known, in that the stems are especially long and wiry and the blooms are carried almost at right angles to the stem without any definite bend. The flowers are large, very full and made up of rather fluted petals. The habit of growth is above the average height, with rather sparse foliage and an abundance of bloom. The flowers appear early in the season and continue to come perfect until the last. A good commercial variety and also an exhibition flower of the highest type.

$\$ 1.00$

VIRGINIA LOUISE. No. 125. Decorative. Amaranth pink, shading to a Tyrian pink at the center. A large and beautiful flower of a regular formation with perfect centers and in a most attractive coloring, which makes it suitable either for cutting or exhibition. It is a tall growing variety with fine stems and keeping qualities.

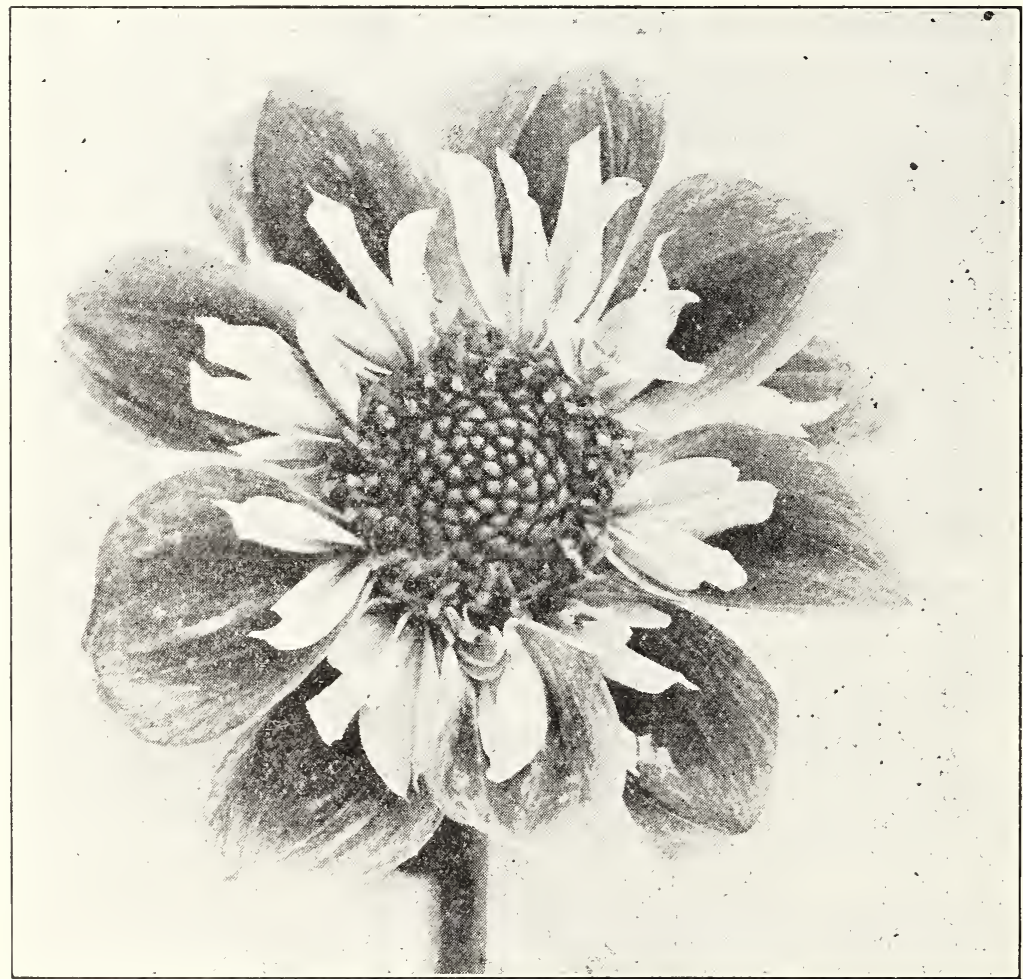

COLLARETTE TYPE 


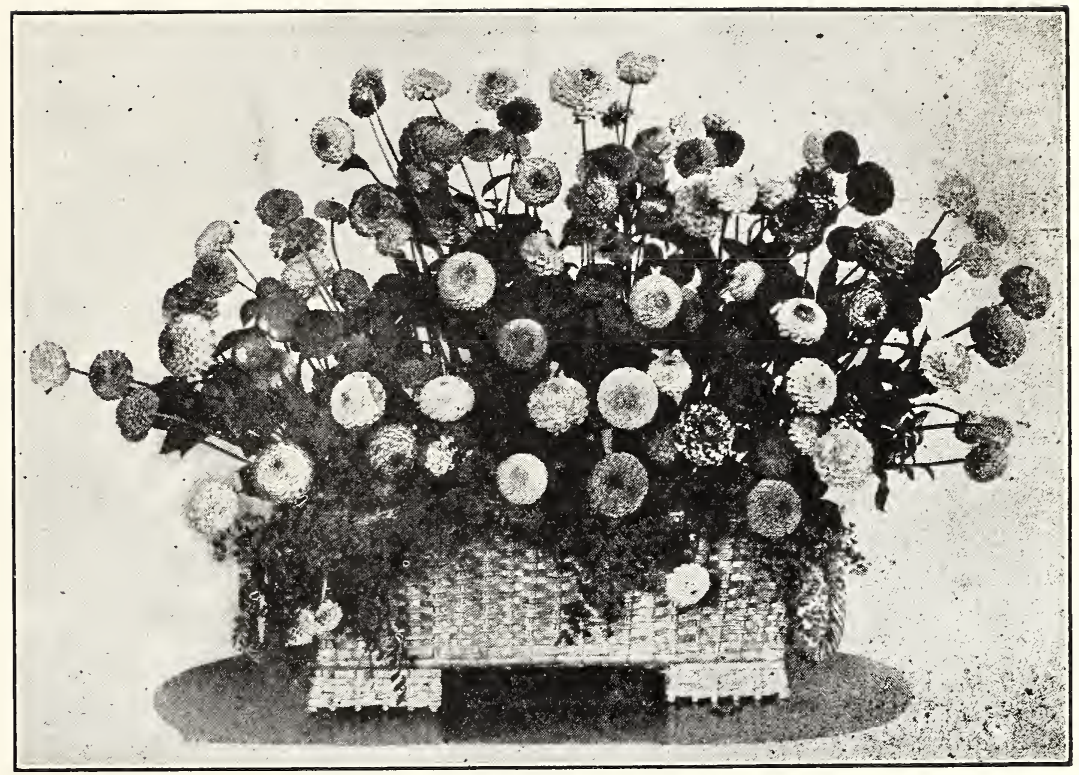

\section{POMPON DAHLIAS}

We are listing all of the varieties of this type together under the one heading, because most growers really consider them as being different from the large flowering dahlias which have been described in the main body of the catalog.

The flowers are small and ball shaped, perfectly double to the center, and are usually made up of very small and quilled petals. For exhibition purposes in order to compete for prizes, the flowers must be less than two inches in diameter; however, the larger ones are as fully useful for decorative effects.

The demand for pompon dahlias has greatly increased in recent years because they are almost indispensible for small decorations and have many uses where the larger sorts would be out of the question. They come in almost all colors, bloom freely and have excellent keeping qualities.

Our collection of these has been carefully selected and all the inferior varieties have been discarded; we offer none but what have good long stems and with practically perfect centers even way late in the season.

There is considerable confusion in the naming of the different pompons; in many instances the same flower being offered under different names and again the same name may be used for two or more different ones. The descriptions given are of those grown in our fields and we believe all are correctly named.

ALEWINE. No. 205. White, flushed and tipped with lavender pink; fine for cut flowers.

35 cents

ALICE ROCKWOOD. No. 795. A new variety in a pleasing shade of old rose. The flowers are rather large with extra long stems. 35 cents

AMBER QUEEN. No. 31. Amber, shaded with apricot. Average size flowers of perfect form on rather low bushes. 35 cents 
ANNA VON SCHWERIN. No. 683. The color is a most delicate shade of light pink, without a trace of lavender, and blends off to a nearly white center; a shade which we have not had in a pompon. The flowers are small, of absolutely perfect formation and stay so until the end of the season. After having grown this variety for several seasons, we still consider it the best all-purpose pompon in cultivation today.

50 cents

ARIEL. No. 403. Deep orange buff. A fine flower on extra long stems, and a tall growing bush.

50 cents

BABY MARIE OSBORNE. No. 780. A deep bright yellow. A new California pompon which will take a place at the head of the list. The flowers are of medium size, perfect form and with long stems.

50 cents

BLUSH GEM. No. 719. Pale pink, edged with cerise. A small flower and very free bloomer.

50 cents

BOBBINETTE. No. 305. Light rose pink, heavily tipped with a deep aster purple. A fine new pompon of just the right size, with always closed centers. The stems are thin and wiry, but stiff and erect.

50 cents

BURGUNDER. No. 446. Dark Bordeaux red. Small and perfect with long stems.

50 cents size.

CANARY. No. 279. Yellow. Fine stems and perfect flowers of average

CATHERINE. No. 402. Rich golden yellow and one of the very best pompons in this color. Medium size flowers which are always perfect.

35 cents

CLARA HARSH. No. 710. Yellow tipped crimson. One of the older varieties and still very popular. Medium size flowers.

35 cents

DAISY. No. 644. Amber, shading to salmon. An old variety of which there is never enough to supply the demand. The flowers are small, never show centers and have extra long stems.

50 cents

E. F. JUNKEER. No. 805. A sort of light chamois pink, a very delicate shade: Fair sized flowers useful for any purpose. 50 cents

GIRLIE. No. 726. Lavender pink. A fine flower in a beautiful shade. of average size, good formation and excellent stems; a great favorite.

50 cents

GRETCHEN HEINE. No. 277. Creamy white, edged pink. Has always been very popular with both amateurs and commercial growers, because of the dainty coloring. The flowers are of medfum size and have very good stems.

35 cents

GRUSS AM WEIN. No. 245. Crushed strawberry, a most distinct color and very pleasing. Average size on rather low bushos.

50 cents

HERBSTZEITLOSE. No. 607. White, tipped with soft lilac. An extra good new sort from Germany.

35 cents

IDEAL. No. 715. Light yellow. Small flowers, always perfect and with long stems.

35 cents

JOE FETTI. No. 695. Pure white. A good white in a regular, perfect pompon type, of smail size and fine stems.

50 cents

JOHNNIE. NO. 212. Crimson maroon. Very perfect flowers, a standard in this type to which others are compared.

50 cents 
JONKHEER VON CITTERS. No. 678. A most striking combination of yellow, sharply tipped with orange red, making it very attractive on the bush and also especially good for cutting purposes, as the bright colors blend in with any decorations. The flowers are rather large and have exceptionally good stems. This is one of our recent importations from Holland and has proven to be most popular.

35 cents

KUPFER. No. 46. Coppery rose. This is really a meritorious pompon of German origin which has been somewhat overlooked. We now have a fair stock of it and are offering a limited quantity of roots.

35 cents

LITTLE BEAUTY. No. 393. Pink. Medium size flowers, made up of many tubular petals. Fine stems.

35 cents

LITTLE JEAN. No. 742. Cream, heavily tipped with tan. A fine bicolored flower of smail size and goed stems.

50 cents

MAROON. No. 230. Dark maroon. Rather large, but of fine form and shape. Dwarf growth.

35 cents

PEE-WEE. No. 802. Yellow, shading to brown center. Small flowers of ideal form, exceptionally good for exhibition.

35 cents

PRINCE CHARMING. No. 334. Lavender, heavily tipped purple. Rather large with extra long stems. Another old favorite which has been popular for years.

35 cents

PURE LOVE. No. 63. Deep lilac. (Liseran purple-Ridgway). Fairly large flowers with perfect centers on long stems.

50 cents

RIVAL. No. 775. Dark red. A very fine flower in color resembling the Pride of Calitornia decorative. This is one of our best sellers and we never have enough stock of it to fill all orders.

50 cents

SKEEZIX. No. 700. Soft lavender. A new California variety of much merit. Fine shape and size with good stems.

35 cents

SUINEEAM. No. 655. Crimson red. A good old time variety in just the right size. lood form and good stems.

50 cents

TITA.U. No. 822. Orange red. One of the finest red pompons, the stocis of which we received from Holland some years ago, but the demand for it has been such that our stock is still very limited. The color is most brilliant, the stens are perfect, the form is fine and size a little above the average. will become very popular.

50 cents

TOMMIY KEITH. No. 635. Cardinal red, tipped white, a very striking contrast, and the flowers all come true. Good size, form and stem.

35 cents

ZOE. No. 794. Pure yellow. Very closely resembles Catherine, and is just about as good. There is enough difference in the shade of color and habit of growth to make the two distinct.

50 cents

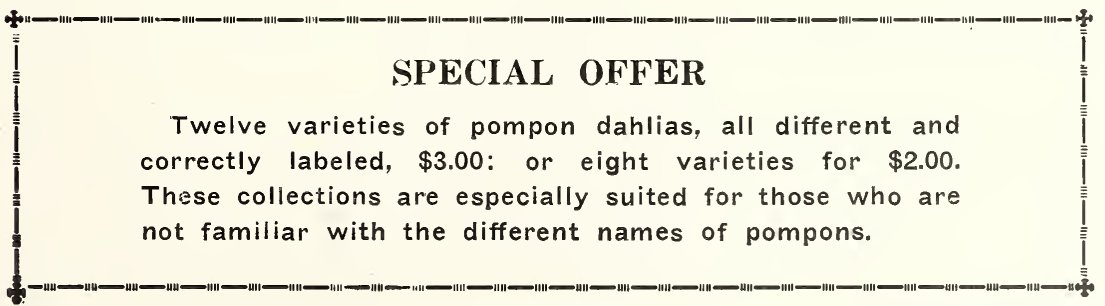




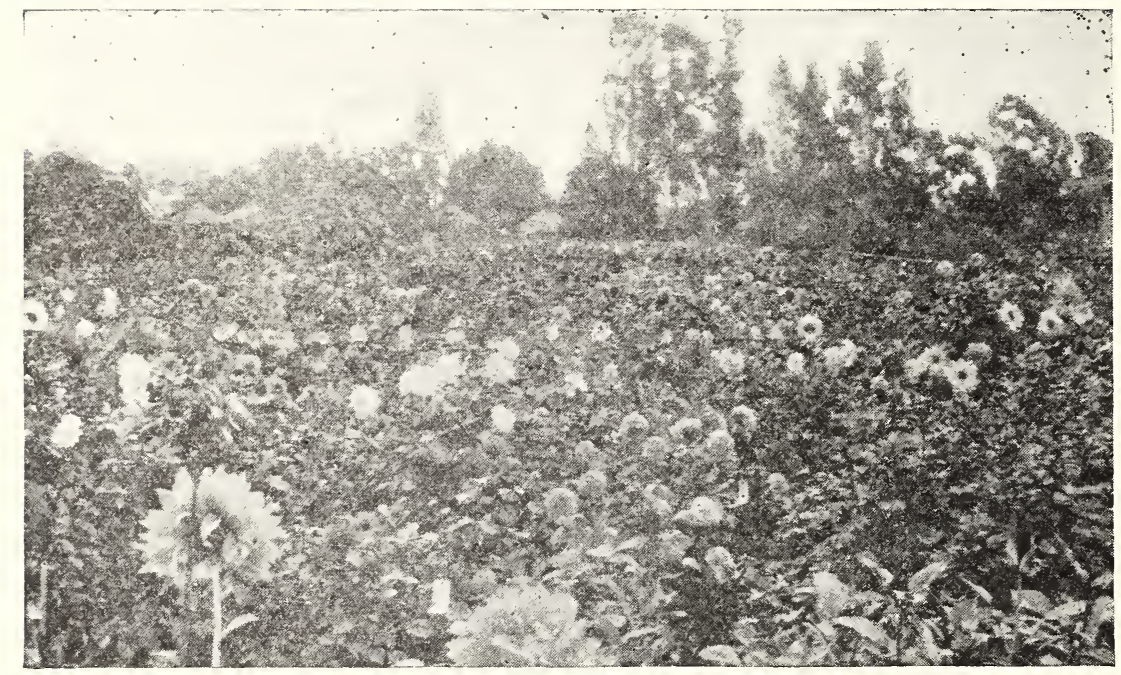

\section{DAHLIA SEED}

Dahlias are easily grown from seed and the plants will bloom the first season, and will make as large bushes and produce as many flowers as if grown from roots. This is not generally known because we are continually receiving letters which read substantially as follows: "I have just seen some seedling dahlias in a neighbor's garden, and was told they wore grown from seed obtained from you. The flowers were simply gorgeous, and I had no idea such beautiful dahlias could be raised from seed."

Furthermore, a iarge percentage of the seedlings from high grade seed should have double flowers, but these results cannot be had if an in. ferior strain is planted, and it is simply a waste of time unless you get seed which has been carefully selected from the best double varieties.

This selection is easily possible in Southern California, because our climatic conditions are such that the seed produced here is superior to that grown anywhere else. We have an exceptionally long growing season, as may be noted from the above cut, which is a view of a portion of our gardens late in November, and for this reason it is not necessary to harvest the seed until late in the year. This condition allows the best and most double varieties to form seed, which is not possible in localities where the growth is stopped earlier in the season.

But it must be borne in mind that the seedling dahlias will be entireiy new varieties, and, while some may resemble the parent plant, there will always be differences, and in many cases there will be no resemblance whatever to the parent. This is because the dahlia has been so highly developed through a long period of years that our present types are far removed from their original ancestors as found growing wild, and also due to the fact that the pollen from one flower is naturally distributed over many others, resulting in the natural crossing of varieties. 
However, it is just this uncertainty that makes the growing of seedlings so interesting and there is always the possibility of developing a new variety which will be superior to any we have as yet; final perfection in the dahlia has by no means been attained.

Much has been written about the artificial crossing of dahlias to get flowers with certain characteristics, but our experience has shown that this method does not work out in practice, and our best seedlings have invariably come trom seed which was produced naturally. So we have given up hand pollenation and depend entirely on natural agencies to distribute the pollen from one flower to another; but we do exercise the greatest care in the selection of the parent plants, and we believe that is the great essential in producing seed. That our seed is fully equal to any, whether advertised as hand crossed or not, is evidenced by the glowing reports we are continually receiving from our customers of the successes they have had with it.

\section{The Seed is Put in Different Grades as Follows:}

EXTRA SELECTED MIXED. This is as choice a grade of seed as can be produced anywhere, and we sincerely believe that it will produce as many fine seedlings as any strain on the market today, no matter at what price it may be advertised. The quality of any dahlia seed depends entirely upon the care used in the selection of the parent varieties; this mixture is made up solely from the decorative, hybrid cactus and peony types, all others are excluded, and the seed is taken only from those which have the largest flower's in the most desirable colors and the best of stems. Put up in packets at 50 cents and $\$ 1.00$ each.

STANDARD GRADE. This is a high grade seed harvested front our main fields, where the different varieties are planted in large blocks and the cross pollenation is not so general; for this reason, this grade is more likely to produce seedlings more nearly resembling the parent type. It may be had in separate types; DECORATIVE, PEONY, HYBRID CACTUS, SHOW, COLLARETTE, POMPON or MIXED. Put up in packets at 25 cents, 50 cents and $\$ 1.00$ each.

SPECIAL GRADE. For the benefit of those who wish to know the parentage of their seedlings, we gather every season a limited quantity of seed from named varieties and offer it under the name of the parent plants. We do not recommend this grade as being any better than our Extra Selected Mixed, but it is being offered solely to supply the increasing demand for seed from named varieties. It is entirely impossible to give a list of the varieties from which this seed may be had, as at the time this is written, the seed is not yet harvested. However, we will be pleased to send a list to anyone interested any time after January fifteenth on a special request. Owing to the extra expense of handling small quantities this is only put up in packets at $\$ 1.00$ each.

Complete cultural directions for the growing of seedlings are enclosed in each packet of seed. 


\section{SPECIAL COLLECTIONS}

For the benefit of those who are just starting in to grow dahlias and are not familiar with the different names, or who do not care to select particular varieties, we put up a number of special collections. These are priced according to the grade of dahlias they contain and represent values considerably over the catalog price. No two dahlias are alike in any of these collections, excepting possibly in Number 1, and different ones may be ordered without duplication.

The selection of varieties in these collections must, in all cases, be left to us.

No. 1. This is made up entirely of unnamed seedlings, all of which have real merit, but cannot be introduced as new varieties because they do not come up to our standards, or else closely resemble others already established. Some of the roots in this collection may be duplicated as the different seedlings are not kept separate after digging. Twelve Roots for $\$ 2.00$

No. 2. Twelve different varieties in several classes and colors each one correctly labeled. This collection is made up of older dahlias and contains many of the standard commercial sorts.

$\$ 2.00$

No. 3. Twelve dahlias selected from the newer and better varieties. All different and each one correctly labeled. This collection has always been one of our most popular sellers.

$\$ 3.00$

No. 4. Twelve of the more recent introductions, every one properly labeled and no two alike. This collection is an exceptionally good value and contains dahlias which will be a credit to any garden.

$\$ 5.00$

No. 5. Twelve very high grade dahlias which, if ordered separately would catalog between fifteen and twenty dollars. A remarkably good value as some of our best dahlias are put in.

$\$ 10.00$

No. 6. Six of the same grade as above, representing a value between seven and ten dollars.

$\$ 5.00$

No. 7. Pompons only-eight different varieties correctly named. $\$ 2.00$

No. 8. Twelve different pompons, named and labeled.

$\$ 3.00$

No. 9. Novelty Collection 1928. This contains seven of the new dahlias which we introduced last year: one root each of Aramis, Golden Rule, Gypsy Maid, Hermoine, Nanon Louise, Princess Gerane, Virginia Louise. The seven for

$\$ 10.00$

No. 10. Novelty Collection 1929. One each of our new dahlias offered for the first time this season and described on page five of this catalog. The six for

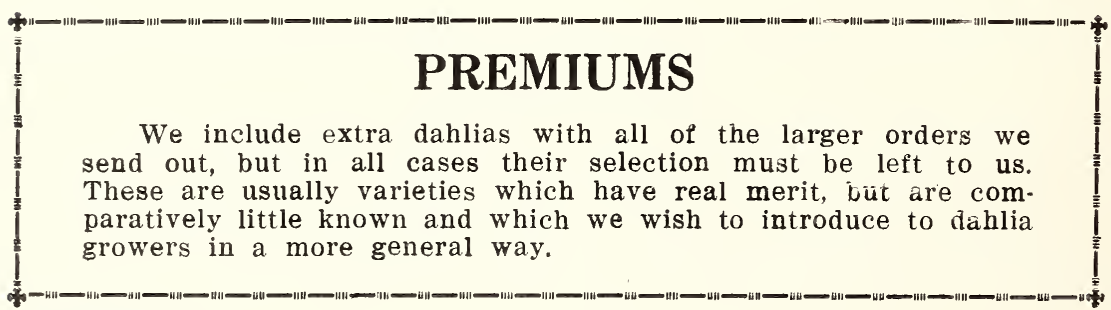


